\title{
Autotrophic Metabolism of Formate by Thiobacillus Strain A2
}

\author{
By D. P. KELLY,* ANN P. WOOD,* J. C. GOTTSCHAL $\dagger$ \\ AND J. G. KUENEN† \\ * Department of Environmental Sciences, University of Warwick, Coventry CV4 7AL \\ $\dagger$ Laboratorium voor Microbiologie, University of Groningen, Haren (Gr.), \\ The Netherlands
}

(Received 5 January 1979; revised 28 February 1979)

\begin{abstract}
Thiobacillus A2 grew on formate as its sole source of carbon and energy. Growth was autotrophic: formate and carbon dioxide were equivalent as carbon sources during growth on formate. Carbon dioxide was fixed by the Calvin cycle in formate- or thiosulphate-grown bacteria which contained comparable high specific activities of ribulosebisphosphate carboxylase. Formate incorporated by bacteria growing heterotrophically or on thiosulphate showed more restricted metabolism, particularly providing carbon for purines. Bacteria growing on formate or thiosulphate assimilated acetate but showed disproportionately high incorporation into glutamate, proline, arginine, leucine, pyrimidines and lipid. Growth kinetics on formate were studied using extended cultures held at constant formate concentrations at $\mathrm{pH} 7 \cdot 8$. Yield was a function of substrate concentration and growth rate, which were linearly related in the range 4 to $40 \mathrm{~mm}$-formate. Formate was an inhibitory substrate at higher concentrations. A computer analysis of the inhibited growth kinetics indicated $K_{\mathrm{s}}$ and $K_{1}$ values of 26.5 and $187 \mathrm{mM}$-formate, respectively, and a true $\mu_{\max }$ of $0.299 \mathrm{~h}^{-1}$.
\end{abstract}

\section{INTRODUCTION}

Thiobacillus A2 (Taylor \& Hoare, 1969) is a facultatively autotrophic chemolithotroph capable of autotrophic growth on thiosulphate plus carbon dioxide and heterotrophic growth on a wide range of organic substrates (Kelly, 1973; Wood \& Kelly, 1977). Taylor \& Hoare (1969) demonstrated the presence of an inducible formate dehydrogenase in the organism and showed that it could grow on formate as sole source of carbon and energy. However, no information was obtained about growth kinetics or yields on formate, or about the mechanism by which formate was metabolized. The latter was of particular interest since the organism was known to use the Benson-Calvin reductive pentose phosphate cycle during autotrophic growth on thiosulphate, and the question to be resolved was whether this mechanism also operated during growth on formate (as in Pseudomonas oxalaticus and Paracoccus denitrificans) or whether alternative pathways such as those used by methylotrophs were present. We have sought to answer this question and to study growth kinetics using both extended culture (Dijkhuizen \& Harder, 1975) and continuous chemostat culture methods.

\section{METHODS}

Organism and culture conditions. Thiobacillus A2, originally obtained from Dr D. S. Hoare, was maintained on agar slants of thiosulphate medium (Wood \& Kelly, 1977) or medium with $0 \cdot 1 \mathrm{M}$-sodium formate. For growth experiments involving assimilation of ${ }^{14} \mathrm{C}$-labelled substrates, cultures were normally grown in 20 or $50 \mathrm{ml}$ medium in $250 \mathrm{ml}$ Erlenmeyer or 'nephlos' flasks (Wood \& Kelly, 1977) shaken at $30^{\circ} \mathrm{C}$. Growth in nephlos flasks was monitored as increase in absorbance at $440 \mathrm{~nm}$ using a Unicam SP600 spectrophotometer with a test tube attachment. Growth at controlled $\mathrm{pH}$ values and in extended culture (see below) 
was studied using 21 cultures in an $\mathrm{LH}$ Engineering $\mathrm{CC} 1500$ fermenter, maintained at $30^{\circ} \mathrm{C}$ with aeration $\left(500 \mathrm{ml} \mathrm{air} \mathrm{min}^{-1}\right)$ and stirred at $500 \mathrm{rev} \cdot \mathrm{min}^{-1}$. The $\mathrm{pH}$ was poised at the desired value by automatic titration with 2 or $10 \mathrm{M}$-formic acid using an EIL model 91B or $9150 \mathrm{pH}$ controller and glass dual electrode with remote reference electrode. The principle of maintaining $\mathrm{pH}$ during growth on formate using formic acid meant that the formate concentration in the culture medium was held at a constant value, and growth of the culture could continue exponentially until some factor other than formate became limiting. Such growth conditions have been called 'extended cultures' (Dijkhuizen \& Harder, 1975) and enabled growth rates and yields to be measured over a range of fixed formate concentrations in the culture vessel. Actual 'steady-state' formate concentrations during extended cultures were measured using the procedure of Lang \& Lang (1972). Growth in extended cultures was monitored turbidimetrically and by replicate dry weight determinations for each growth condition studied. Viable counting on agar media of serial dilutions from cultures demonstrated that all the organisms growing on formate also formed colonies on media with thiosulphate, glucose or sucrose and were characteristically Thiobacillus A2. In chemostat cultures at constant $\mathrm{pH}$, sodium formate was the growth-limiting nutrient.

Incorporation of ${ }^{14} \mathrm{C}$-labelled substrates. Assimilation of $\left[{ }^{14} \mathrm{C}\right]$ formate, ${ }^{14} \mathrm{CO}_{2}$ or $\left[\mathrm{U}_{-}{ }^{14} \mathrm{C}\right]$ acetate was monitored using membrane filtration methods (Tuovinen \& Kelly, 1973); fractionation, analysis and chromatography of labelled bacteria was done by procedures described previously (Kelly, 1967, 1969, 1970; Eccleston \& Kelly, 1973). For growth in the presence of ${ }^{14} \mathrm{CO}_{2}$, flasks were sealed with 'Suba-seal' vaccine stoppers. Short-term incorporation of $\left[{ }^{14} \mathrm{C}\right]$ formate or ${ }^{14} \mathrm{CO}_{2}$ was studied using bacterial suspensions harvested from formate-grown cultures, washed and resuspended in $25 \mu \mathrm{M}-\mathrm{K}_{2} \mathrm{HPO}_{4}, \mathrm{pH} 7 \cdot 4$. Bacteria $(10 \mathrm{ml})$ were stirred in $50 \mathrm{ml}$ beakers or $50 \mathrm{ml}$ sealed conical flasks for $3 \mathrm{~min}$ after addition of $1 \mathrm{ml} 0.06 \mathrm{M}$-sodium formate, then $1.5 \mathrm{ml}$ of either sodium $\left[{ }^{14} \mathrm{C}\right]$ formate $(75 \mu \mathrm{Ci})$ or $\mathrm{Na}_{2}{ }^{14} \mathrm{CO}_{3}(200 \mu \mathrm{Ci})$ were added, and samples $(4 \mathrm{ml})$ were withdrawn into ethanol $(20 \mathrm{ml})$ at $70{ }^{\circ} \mathrm{C}$ after $0.5,1.5$ and $3.0 \mathrm{~min}$. The ethanol-soluble cell constituents were separated chromatographically as described by Quayle \& Keech (1959). ${ }^{14} \mathrm{C}$-labelled compounds detected by radioautography and identified by their comparative chromatographic mobility were then eluted for further chromatography with appropriate reference compounds.

Assay of ribulosebisphosphate carboxylase [3-phospho-D-glycerate carboxylyase (dimerizing); EC 4.1.1.39]. Bacteria were harvested from steady-state chemostat cultures on formate by centrifugation $\left(2{ }^{\circ} \mathrm{C}, 12000 \mathrm{~g}, 15 \mathrm{~min}\right.$ ), washed with $0 \cdot 1 \mathrm{M}$-Tris/maleate buffer, $\mathrm{pH} 8 \cdot 0$, and suspended at 10 to $40 \mathrm{mg} \mathrm{ml}^{-1}$ either in similar buffer or in $0.1 \mathrm{M}-\mathrm{Tris} / \mathrm{HCl}, \mathrm{pH} 8.2$, containing $20 \mathrm{~mm}-\mathrm{MgCl}_{2}, 5 \mathrm{~mm}-\mathrm{NaHCO}_{3}$ and $0.5 \mathrm{~mm}-$ dithiothreitol. Bacteria were sonicated $(5 \times 30 \mathrm{~s}$ at maximum power) in the presence of $1 \mathrm{~g}$ Ballotini glass beads $(0.11 \mathrm{~mm})$ per $2 \mathrm{ml}$ suspension using an MSE ultrasonic disintegrator. The extracts used for enzyme assay were the supernates obtained from centrifuging at $20000 \mathrm{~g}$ for $20 \mathrm{~min}$. Two assay procedures were used.

(i) Spectrophotometric method (London \& Rittenberg, 1966). Reaction mixtures (1 ml) at pH 8.6 contained ( $\mu$ mol, unless indicated otherwise): Tris/maleate, $250 ; \mathrm{MgCl}_{2}, 10 ; \mathrm{NaHCO}_{3}, 37$; glutathione, 5; ATP, 3; NADH, 0.14; phosphoglycerate kinase [ATP:3-phospho-D-glycerate 1-phosphotransferase; EC 2.7.2.3], $12 \mu \mathrm{g}$; glyceraldehyde phosphate dehydrogenase [D-glyceraldehyde-3-phosphate: $\mathrm{NAD}^{+}$oxidoreductase (phosphorylating); EC 1.2.1.12], $150 \mu \mathrm{g}$; ribulose 1,5-bisphosphate, 0.24 ; crude extract, 0.02 to $0.2 \mathrm{mg}$ protein. Activity was directly proportional to the added protein concentration and the reaction was linear for at least $6 \mathrm{~min}$. No detectable activity was found if any one of ribulose bisphosphate, phosphoglycerate kinase, glyceraldehyde phosphate dehydrogenase, NADH or ATP was omitted.

(ii) ${ }^{14} \mathrm{CO}_{2}$-fixation method. Reaction mixtures $(0.3 \mathrm{ml})$ at $\mathrm{pH} 8.2$ contained $(\mu \mathrm{mol}$, unless indicated otherwise): Tris/HCl, 27; $\mathrm{MgCl}_{2}, 5 \cdot 4$; dithiothreitol, $0 \cdot 135 ; \mathrm{NaH}^{14} \mathrm{CO}_{3}\left(0 \cdot 2 \mu \mathrm{Ci} \mu \mathrm{mol}^{-1}\right), 1 \cdot 85$; ribulose 1,5bisphosphate, 0.2 ; crude extract, 0.05 to $0.5 \mathrm{mg}$ protein. Reactions were initiated by addition of ribulose 1,5-bisphosphate and samples $(50 \mu \mathrm{l})$ were removed after 30,60, 90 and $120 \mathrm{~s}$ into $200 \mu \mathrm{l}$ acetic acid at $60^{\circ} \mathrm{C}$ in scintillation vials. After $20 \mathrm{~min}$ at $60^{\circ} \mathrm{C}$, vials were cooled, $4 \mathrm{ml}$ scintillation fluid (toluene, 21 ; Triton-X100, 1 1; diphenyloxazole, $10 \mathrm{~g}$ ) were added and ${ }^{14} \mathrm{C}$ was assayed in a Nuclear Chicago scintillation counter. Prior to activity measurements, the extract was activated by incubation for 5 to $10 \mathrm{~min}$ at room temperature $\left(18\right.$ to $\left.20^{\circ} \mathrm{C}\right)$ as described by Badger \& Lorimer (1976). There was a linear relationship between ${ }^{14} \mathrm{CO}_{2}$-fixation and time for at least $120 \mathrm{~s}$ under these conditions. Activity was proportional to protein concentration.

Protein contents of crude extracts and bovine serum albumin standards were measured by a microbiuret method (Kuenen \& Veldkamp, 1972) or by Lowry's Folin procedure.

Chemicals. All radiochemicals were from The Radiochemical Centre, Amersham. All reagents were of analytical or chromatographic grade. Ribulose 1,5-bisphosphate and ATP were from Sigma; glutathione, NADH, phosphoglycerate kinase and glyceraldehyde phosphate dehydrogenase were from Boehringer. The latter enzyme was dialysed before use against 11 of Tris/maleate buffer for $22 \mathrm{~h}$ at $4{ }^{\circ} \mathrm{C}$ to remove ammonium ions, which were inhibitory to the carboxylase. 
Table 1. Specific growth rates of Thiobacillus A2 at constant $p H$ values in extended exponential growth with constant formate concentration $(25 \mathrm{mM})$

$\begin{array}{ccc}\text { Culture pH } & \begin{array}{c}\text { Specific growth } \\ \text { rate, } \mu \\ \left(\mathrm{h}^{-1}\right)\end{array} & \begin{array}{c}\text { Growth yield } \\ \text { [g dry wt } \\ (\text { mol formate) }\end{array} \\ 7.2 & 0 \cdot 080 & 2.93 \\ 7.6 & 0.092 & 3.99 \\ 7.8 & 0.154 & 3.64 \\ 8.0 & 0 \cdot 103 & 4 \cdot 19 \\ 8.4 & 0.057 & 3.20\end{array}$

Table 2. Relationship between formate concentration, specific growth rate and yield in extended exponential cultures of Thiobacillus A2 at pH $7 \cdot 8$

\begin{tabular}{|c|c|c|}
\hline $\begin{array}{l}\text { Constant } \\
\text { formate concn } \\
\text { (mM) }\end{array}$ & $\begin{array}{c}\text { Specific growth } \\
\text { rate, } \mu \\
\left(\mathrm{h}^{-1}\right)\end{array}$ & $\begin{array}{c}\text { Growth yield } \\
\text { [g dry wt } \\
\text { (mol formate })^{-1} \text { ] }\end{array}$ \\
\hline $3 \cdot 6$ & 0.014 & $1 \cdot 50$ \\
\hline $3 \cdot 8$ & 0.011 & $1 \cdot 40$ \\
\hline $5 \cdot 0$ & 0.025 & $1 \cdot 75$ \\
\hline $7 \cdot 8$ & 0.034 & $2 \cdot 44$ \\
\hline $16 \cdot 4$ & $0 \cdot 116$ & 2.94 \\
\hline $23 \cdot 4$ & 0.154 & $4 \cdot 26$ \\
\hline $41 \cdot 2$ & 0.198 & $2 \cdot 40$ \\
\hline $87 \cdot 9$ & $0 \cdot 168$ & $2 \cdot 51$ \\
\hline $171 \cdot 4$ & 0.116 & $3 \cdot 59$ \\
\hline $402 \cdot 2$ & 0.027 & 0.99 \\
\hline
\end{tabular}

RESULTS

Growth in batch and extended cultures

Using media initially at $\mathrm{pH} 8 \cdot 2$, growth occurred in shake flask cultures with $\mu=0 \cdot 1 \mathrm{~h}^{-1}$, and the yield was proportional to the initial formate concentration between 20 to $100 \mathrm{~mm}$. The culture $\mathrm{pH}$ rose during batch growth in accordance with the equation for sodium formate oxidation:

$$
2 \mathrm{HCOONa}+\mathrm{O}_{2} \longrightarrow 2 \mathrm{NaOH}+2 \mathrm{CO}_{2}
$$

Constant exponential growth rates and yields were determined for extended cultures (Dijkhuizen \& Harder, 1975) controlled at several $\mathrm{pH}$ values by automatic titration with formic acid to maintain a constant formate concentration $(25 \mathrm{~mm})$ in the culture media (Table 1). The growth rate was maximal at about $\mathrm{pH} 7 \cdot 8$, while the yield was similar between pH 7.6 and 8.0 but decreased at $\mathrm{pH} 7 \cdot 2$ and $8 \cdot 4$.

In extended cultures held at several fixed formate concentrations and poised at $\mathrm{pH} 7 \cdot 8$, the growth rate increased with formate concentration up to about $40 \mathrm{~mm}$; higher concentrations were inhibitory (Table 2). The yield also increased with the increasing growth rate (Table 2). The correlation between increase in yield and increase in growth rate consequent on increased substrate concentration was indicated by the relationship between the reciprocals of yields $\left(Y^{-1}\right)$ and the reciprocals of either formate concentration $\left(s^{-1}\right)$ or growth rate $\left(\mu^{-1}\right)$ (Fig. 1). Since this plot formally relates yield and growth rate in the same manner as described for substrate-limited chemostat cultures (Pirt, 1965), the extrapolation of the line (assuming the relationship in Fig. 1 is linear and not curved) to the $Y^{-1}$ axis gives the apparent true growth yield $\left(Y_{G}\right)$ and the slope gives a measure of the maintenance energy requirement $(m)$. Extrapolation of the line drawn in Fig. 1 indicated $Y_{\mathrm{G}}$ to be $4 \cdot 2 \mathrm{~g}$ dry wt (mol formate) $)^{-1}$ and $m$ to be $7 \mathrm{mmol}$ formate (g dry wt) ${ }^{-1} \mathrm{~h}^{-1}$. Assuming the relationship of $Y^{-1}$ versus $\mu^{-1}$ to be linear, $Y_{G}$ values were also computed [from $Y^{-1}=m^{-1} \mu^{-1}+Y_{G}^{-1}$ ], 


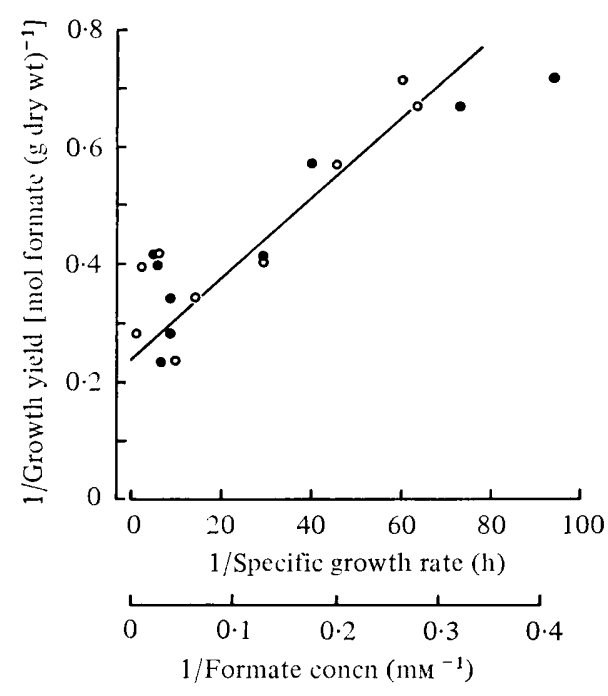

Fig. 1

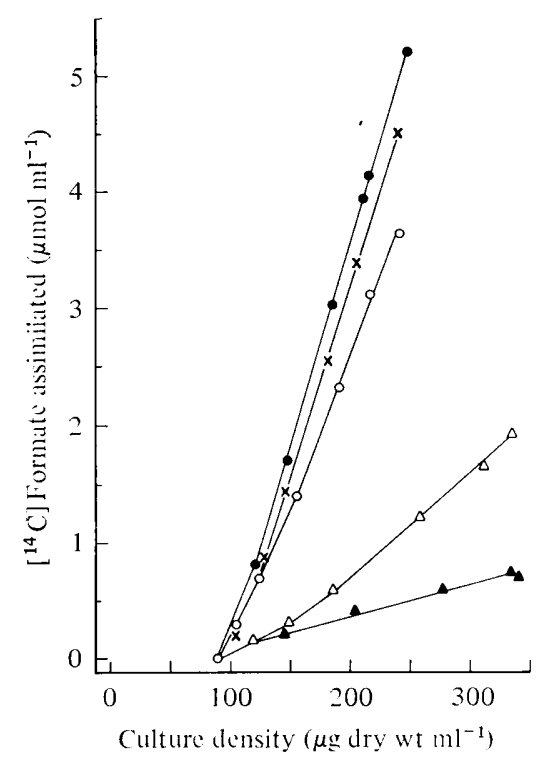

Fig. 2

Fig. 1. Growth rates and yields of Thiobacillus A2 in extended exponential culture at pH $7 \cdot 8$ over a range of concentrations of sodium formate. Reciprocals of growth yields $\left(Y^{-1}\right)$ were plotted against reciprocals of specific growth rate $\left(\mu^{-1}\right)(O)$ or reciprocals of substrate (formate) concentration $\left(\mathrm{mM}^{-1}\right)(\mathrm{O})$, using the data from Table 2 for all formate concentrations between 3.6 and $171.4 \mathrm{~mm} ; 87.9$ and $171.4 \mathrm{~mm}$-formate were growth rate inhibitory.

Fig. 2. Incorporation of $\left.{ }^{[14} \mathrm{C}\right]$ formate into Thiobacillus $\mathrm{A} 2$ during growth of cultures $(10 \mathrm{ml})$ in $250 \mathrm{ml}$ nephlos flasks with $0 \cdot 1 \mathrm{M}$-sodium $\left[{ }^{14} \mathrm{C}\right]$ formate $\left(1 \mu \mathrm{Ci} \mathrm{mi}{ }^{-1}\right)$ under different conditions of $\mathrm{CO}_{2}$ supply. The initial organism density was $90 \mu \mathrm{g} \mathrm{ml}^{-1}$. Cultures were incubated under air in a flask closed with a cotton plug $(O)$; under air in a flask sealed with a rubber stopper $(x)$; under air in a flask sealed with a rubber stopper, but with $\mathrm{KOH}$ pellets in the well of the flask to absorb gaseous $\mathrm{CO}_{2}(\mathrm{O})$; under air containing $10 \%(\mathrm{v} / \mathrm{v}) \mathrm{CO}_{2}$ in a sealed flask $(\triangle)$; or in a flask continuously flushed with sterile $5 \%(\mathrm{v} / \mathrm{v}) \mathrm{CO}_{2}$ in air at $100 \mathrm{ml} \mathrm{min}^{-1}(\Delta)$.

using the first six and seven values of Table 2 , as 3.7 and $3 \cdot 3$, respectively, with correlation coefficients of 0.96 and 0.93 , respectively. The correlation indicates reasonable fit of the data to a linear relationship, but the possibility that the relation tends to a curve (as may also be the case in chemostat culture; J. G. Kuenen, unpublished work) has not been excluded.

\section{Chemostat culture on limiting formate}

Chemostat growth kinetics and their interpretation will be discussed in detail elsewhere (J. C. Gottschal \& J. G. Kuenen, unpublished) and are here used for comparative purposes only. Using $100 \mathrm{~mm}$ input formate concentration, the steady-state formate concentration was less than $0.3 \mathrm{~mm}$ and the value for $Y_{\mathrm{G}}$ could be calculated from $Y^{-1}$ versus $D^{-1}$ and from $q_{\text {tormate }}$ versus $D$ plots to be between 3.0 and $3.3 \mathrm{~g}$ dry wt (mol formate) ${ }^{-1}$.

\section{Equivalence of carbon dioxide and formate-carbon during growth on formate in batch culture}

During exponential growth on $\left[{ }^{14} \mathrm{C}\right]$ formate in sealed shake-flasks containing air depleted of $\mathrm{CO}_{2}$, most newly synthesized Thiobacillus A2 carbon was derived from formate (Fig. 2). Using conditions under which $\mathrm{CO}_{2}$ was available to different extents, the amount of formatecarbon assimilated could be decreased considerably (Fig. 2). In flasks open to normal air, only two-thirds of the cell-carbon came from formate, while continuous purging of the culture with $5 \%(\mathrm{v} / \mathrm{v}) \mathrm{CO}_{2}$ in air reduced this to less than $10 \%$ (Table 3). Under conditions 


\section{Table 3. Effect of availability of carbon dioxide on the growth rate and formate-carbon assimilation by Thiobacillus A2}

Cultures were grown on $0.1 \mathrm{M}$-sodium $\left[{ }^{14} \mathrm{C}\right]$ formate as described in the legend to Fig. 2. Formate assimilation is expressed relative to the increase in biomass (as $\mu \mathrm{mol}$ formate-carbon incorporated per $\mathrm{mg}$ increase in culture dry weight) and as a percentage of the total amount of carbon fixed (assuming the cell carbon content to be $44 \%$ of the dry weight).

$\begin{array}{lccc}\text { Growth condition } & \begin{array}{c}\text { Specific growth } \\ \text { rate, } \mu \\ \left(\mathrm{h}^{-1}\right)\end{array} & \begin{array}{c}\text { Formate } \\ \text { assimilated } \\ {[\mu \mathrm{mol}} \\ \left.(\mathrm{mg} \mathrm{dry} \mathrm{wt)})^{-1}\right]\end{array} & \begin{array}{c}\text { Percentage of } \\ \text { cell-carbon } \\ \text { from formate }\end{array} \\ \text { flask } & 0 \cdot 096 & 24 \cdot 2 & 65.9 \\ \text { flask, } \mathrm{CO}_{2} \text { absorbed by } \mathrm{KOH} & 0.084 & 30 \cdot 4 & 83.0 \\ \mathrm{CO}_{2} \text { in air, sealed flask } & 0.093 & 33 \cdot 2 & 90 \cdot 7 \\ \mathrm{CO}_{2} \text { in air flushed through flask } & 0 \cdot 143 & 8 \cdot 1 & 22.0 \\ & 0.146 & 2 \cdot 8 & 7.7\end{array}$

Table 4. Short-term incorporation of ${ }^{14} \mathrm{C}$-labelled carbon dioxide or formate by suspensions of Thiobacillus A2 previously grown on formate

${ }^{14} \mathrm{C}$-labelled carbonate or formate was added to bacterial suspensions $\left(7 \mathrm{mg} \mathrm{ml}^{-1}\right)$ and samples were taken and analysed as described in Methods. The results show the ${ }^{14} \mathrm{C}$ distribution among compounds in the $80 \%(\mathrm{v} / \mathrm{v})$ ethanol-soluble fraction of the bacteria.

\begin{tabular}{|c|c|c|c|c|c|c|}
\hline \multirow[b]{3}{*}{ Sample time (min) } & \multicolumn{6}{|c|}{${ }^{14} \mathrm{C}$ distribution ( $\%$ of total ${ }^{14} \mathrm{C}$ on chromatogram) } \\
\hline & \multicolumn{3}{|c|}{ Incorporation from ${ }^{14} \mathrm{CO}_{2}$} & \multicolumn{3}{|c|}{ Incorporation from $\left[{ }^{14} \mathrm{C}\right]$ formate } \\
\hline & 0.5 & $1 \cdot 5$ & $3 \cdot 0$ & 0.5 & $1 \cdot 5$ & $3 \cdot 0$ \\
\hline $\begin{array}{l}\text { Total }{ }^{14} \mathrm{C} \text { (c.p.m.) } \\
\text { No. of labelled compounds }\end{array}$ & $\begin{array}{l}38818 \\
19\end{array}$ & $\begin{array}{l}82284 \\
29\end{array}$ & $\begin{array}{l}97989 \\
29\end{array}$ & $\begin{array}{l}22777 \\
19\end{array}$ & $\begin{array}{l}74630 \\
31\end{array}$ & $\begin{array}{l}220030 \\
42\end{array}$ \\
\hline Phosphoglyceric acid & $14 \cdot 6$ & $10 \cdot 6$ & $3 \cdot 4$ & $20 \cdot 9$ & $12 \cdot 8$ & $4 \cdot 5$ \\
\hline Sugar phosphates & $22 \cdot 2$ & $17 \cdot 8$ & $22 \cdot 1$ & $16 \cdot 2$ & $21 \cdot 6$ & $14 \cdot 7$ \\
\hline Phosphoenolpyruvate & $2 \cdot 7$ & 1.9 & $1 \cdot 0$ & $2 \cdot 2$ & 0.9 & 0.2 \\
\hline Glutamic acid & $17 \cdot 6$ & $25 \cdot 4$ & $17 \cdot 9$ & $21 \cdot 0$ & $23 \cdot 7$ & $12 \cdot 1$ \\
\hline Glutamine & $31 \cdot 1$ & $20 \cdot 3$ & $7 \cdot 1$ & $17 \cdot 5$ & $12 \cdot 1$ & $8 \cdot 7$ \\
\hline Aspartic acid & 0.4 & 0.6 & $3 \cdot 1$ & $2 \cdot 6$ & 1.4 & $0 \cdot 8$ \\
\hline Asparagine & $1 \cdot 2$ & $1 \cdot 1$ & $3 \cdot 1$ & $2 \cdot 1$ & $4 \cdot 7$ & $7 \cdot 6$ \\
\hline Leucine, isoleucine, phenylalanine & $1 \cdot 7$ & $4 \cdot 5$ & $13 \cdot 2$ & $3 \cdot 1$ & $8 \cdot 4$ & $13 \cdot 5$ \\
\hline Glycollic acid (?) & $1 \cdot 7$ & $2 \cdot 3$ & $3 \cdot 6$ & $2 \cdot 1$ & $4 \cdot 6$ & 3.8 \\
\hline Alanine & - & - & $1 \cdot 6$ & - & $0 \cdot 6$ & $1 \cdot 1$ \\
\hline Valine & 一 & $1 \cdot 0$ & 1.9 & - & $1 \cdot 5$ & $4 \cdot 9$ \\
\hline Tyrosine & - & $0 \cdot 1$ & $0 \cdot 1$ & 0.9 & $0 \cdot 3$ & $0 \cdot 3$ \\
\hline Citric acid (?) & 一 & 0.9 & $2 \cdot 0$ & $0 \cdot 3$ & $1 \cdot 0$ & $2 \cdot 5$ \\
\hline Phosphogluconic acid (?) & - & - & $\ldots$ & $4 \cdot 4$ & $1 \cdot 2$ & $0 \cdot 6$ \\
\hline $\begin{array}{l}\text { Percentage of total }{ }^{14} \mathrm{C} \text { recovered } \\
\text { in the identified compounds }\end{array}$ & $93 \cdot 2$ & $86 \cdot 5$ & $80 \cdot 1$ & $93 \cdot 3$ & $94 \cdot 8$ & $75 \cdot 3$ \\
\hline
\end{tabular}

of enhanced $\mathrm{CO}_{2}$ supply the growth rate on formate was considerably stimulated (Table 3 ), consistent with growth being dependent on $\mathrm{CO}_{2}$-fixation using energy from formate oxidation.

\section{Short-term incorporation of ${ }^{14} \mathrm{C}$-labelled formate or carbon dioxide by suspensions oxidizing formate}

Suspensions of Thiobacillus A2 oxidized unlabelled sodium formate for 3 min before the addition of high specific activity $\left[{ }^{14} \mathrm{C}\right]$ formate or $\left[{ }^{14} \mathrm{C}\right]$ carbonate and the distribution of fixed ${ }^{14} \mathrm{C}$ was determined after $0.5,1.5$ and $3.0 \mathrm{~min}$ further incubation (Table 4). The pattern of ${ }^{14} \mathrm{C}$-fixation was essentially the same for both substrates, indicating a common pathway for incorporation. Identification of labelled intermediates was based primarily on their chromatographic mobility in several solvents and we are indebted to Professor V. 
Table 5. Ribulosebisphosphate carboxylase activity in Thiobacillus A2 grown in chemostat culture on formate at several dilution rates

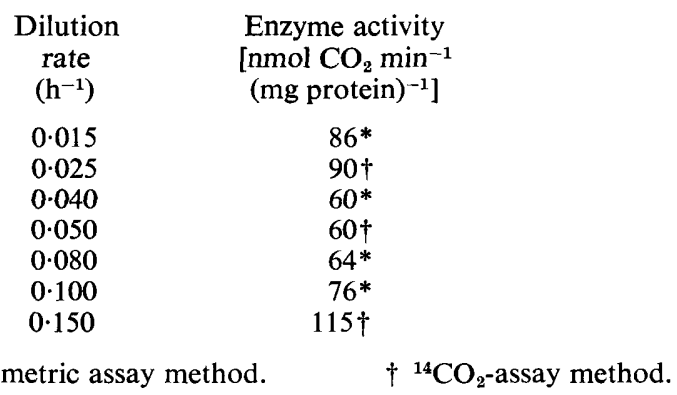

* Spectrophotometric assay method. $\quad+{ }^{14} \mathrm{CO}_{2}$-assay method.

Moses and Professor J. R. Quayle for assistance in identifying some compounds. 3-Phosphoglycerate exhibited the characteristics of a primary product, suggesting the operation of the Calvin reductive pentose phosphate cycle. Compounds chromatographing as glutamate and glutamine accounted for nearly half of the ${ }^{14} \mathrm{C}$ incorporated after $0.5 \mathrm{~min}$ (Table 4), declining to 20 to $25 \%$ after $3 \mathrm{~min}$. This might reflect a large steady-state glutamate/ glutamine pool, but the early incorporation of label into these compounds probably indicated the flow of fixed carbon from phosphoglycerate (via pyruvate) to acetate, and (via phosphoenolpyruvate and $\mathrm{C}_{3}$-carboxylation) to oxaloacetate, followed by citrate synthesis and the formation of glutamate from 2-oxoglutarate by the reactions of the tricarboxylic acid cycle.

\section{Presence of ribulosebisphosphate carboxylase in formate-grown Thiobacillus A2}

Ribulosebisphosphate carboxylase activity was readily detectable in extracts of chemostat-grown bacteria using both spectrophotometric and ${ }^{14} \mathrm{C}$-assay methods. Using either method with appropriately 'activated' extracts (see Methods), activity was linearly proportional to the extract concentration and was only slightly affected by the dilution rate of the culture (Table 5), being distributed around a mean value of about $80 \mathrm{nmol} \mathrm{CO}$ fixed $\min ^{-1}$ (mg protein) $)^{-1}$. For comparison, activity in extracts of organisms grown on thiosulphate in the chemostat at $D=0.025$ to $0.1 \mathrm{~h}^{-1}$ ranged from 50 to $70 \mathrm{nmol} \mathrm{CO}_{2} \mathrm{~min}^{-1}$ $(\mathrm{mg} \text { protein })^{-1}$. The activity in extracts from a culture at $D=0.025 \mathrm{~h}^{-1}\left[90 \mathrm{nmol} \mathrm{CO}_{2} \mathrm{~min}^{-1}\right.$ (mg protein $\left.)^{-1}\right]$ was inhibited by $\left(\mathrm{NH}_{4}\right)_{2} \mathrm{SO}_{4}(72 \%$ by $20 \mathrm{~mm}), \mathrm{K}_{2} \mathrm{HPO}_{4}(48 \%$ by $20 \mathrm{~mm})$ and 6-phosphogluconate $(73 \%$ by $2 \mathrm{~mm})$. Enzyme activity was undetectable $\left[<1 \mathrm{nmol} \mathrm{CO}_{2}\right.$ $\min ^{-1}$ (mg protein $)^{-1}$ ] in Thiobacillus A2 grown on fructose or acetate.

Ribulosebisphosphate carboxylase in extracts (culture $D=0.025 \mathrm{~h}^{-1}$ ) exhibited oxygenase activity, yielding 3-phosphoglycerate and 2-phosphoglycollate. Oxygen uptake was dependent on ribulose bisphosphate $(0.33 \mathrm{~mm})$ and was inhibited by $\mathrm{CO}_{2}$ : the $\mathrm{O}_{2}$ consumption with $\mathrm{CO}_{2}$ at $0.65,2 \cdot 0,3.3$ and $5.3 \mathrm{~mm}$ was $4,3,2.5$ and $1.05 \mathrm{nmol} \mathrm{min}^{-1}\left(\mathrm{mg}\right.$ protein) ${ }^{-1}$.

\section{Comparison of incorporation into amino acids and nucleic acids of ${ }^{14} \mathrm{C}$ from formate, carbon dioxide or acetate by Thiobacillus A2 growing under a variety of conditions}

Batch cultures growing exponentially either autotrophically on thiosulphate or formate, or heterotrophically on acetate, succinate or sucrose, were supplied with the ${ }^{14} \mathrm{C}$-labelled compounds and the bacteria were killed and analysed after 30 to 510 min further growth. Gross labelling patterns proved similar for both long-term and short-term labelling. Labelling patterns were similar for ${ }^{14} \mathrm{C}$ distribution among major cell fractions when all cell-carbon was being derived from the labelled substrate (Table 6), as occurred during growth on $\left[{ }^{14} \mathrm{C}\right]$ formate or $\left[{ }^{14} \mathrm{C}\right]$ acetate alone or thiosulphate plus ${ }^{14} \mathrm{CO}_{2}$. Disproportionately 


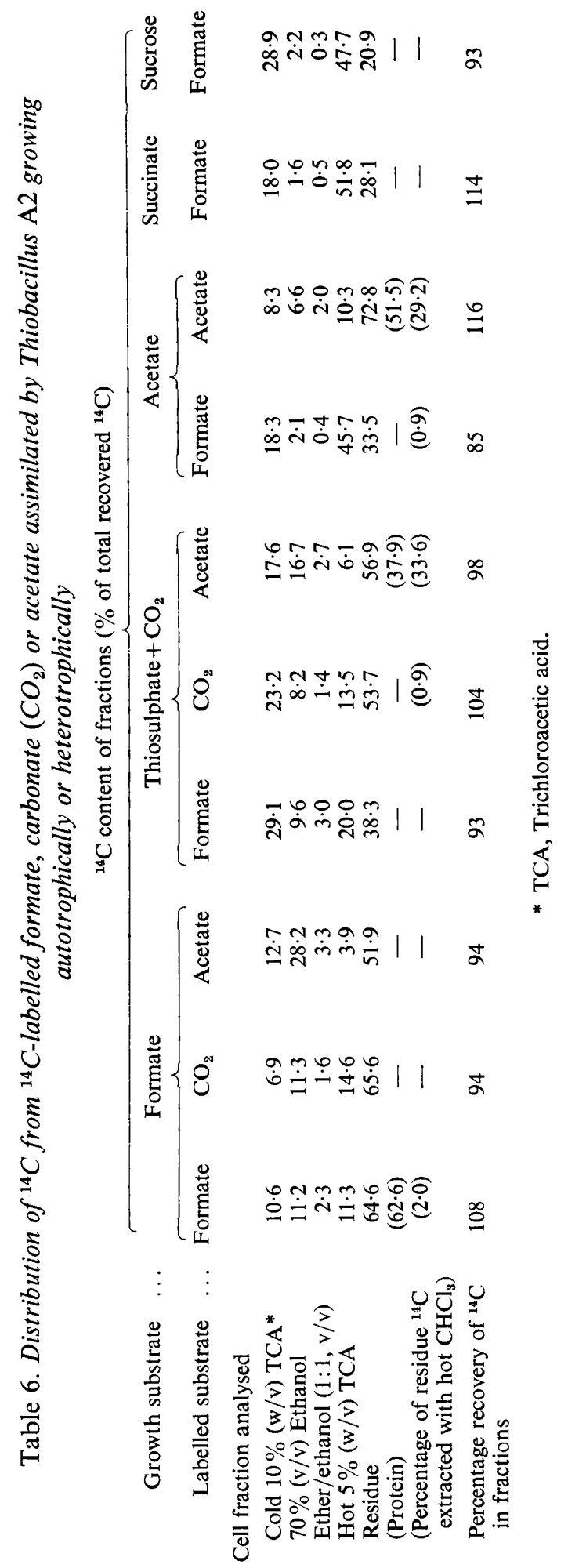




\section{Table 7. Distribution of ${ }^{14} \mathrm{C}$ among nucleic acid bases after assimilation of ${ }^{14} \mathrm{C}$-labelled formate, carbonate $\left(\mathrm{CO}_{2}\right)$ or acetate by Thiobacillus A2 growing autotrophically or heterotrophically}

Hydrolysed nucleic acids from hot $5 \%(\mathrm{w} / \mathrm{v})$ trichloroacetic acid fractions (Table 6) were partitioned by two-dimensional ascending paper chromatography (Eccleston \& Kelly, 1973).

$\begin{array}{llcccc}\begin{array}{l}\text { Labelled } \\ \text { substrate }\end{array} & \text { Growth substrate } & \text { Guanine } & \text { Adenine } & \begin{array}{c}\text { Uridylic } \\ \text { acid }\end{array} & \begin{array}{c}\text { Cytidylic } \\ \text { acid }\end{array} \\ \text { Formate } & \text { Formate } & 27 \cdot 4 & 19 \cdot 1 & 18 \cdot 1 & 35 \cdot 4 \\ & \text { Thiosulphate }+\mathrm{CO}_{2} & 56 \cdot 8 & 30 \cdot 1 & 2 \cdot 9 & 10 \cdot 2 \\ & \text { Acetate } & 52 \cdot 8 & 39 \cdot 6 & 2 \cdot 7 & 4 \cdot 8 \\ & \text { Succinate } & 55 \cdot 2 & 38 \cdot 6 & 2 \cdot 4 & 3 \cdot 8 \\ \mathrm{CO}_{2} & \text { Sucrose } & 58 \cdot 5 & 39 \cdot 4 & 0 \cdot 6 & 1 \cdot 5 \\ & \text { Formate } & 17 \cdot 5 & 11 \cdot 4 & 27 \cdot 9 & 43 \cdot 2 \\ \text { Acetate } & \text { Thiosulphate }+\mathrm{CO}_{2} & 19 \cdot 3 & 11 \cdot 6 & 25 \cdot 6 & 43 \cdot 5 \\ & \text { Formate } & 6 \cdot 0 & 6 \cdot 4 & 35 \cdot 8 & 51 \cdot 8 \\ & \text { Thiosulphate }+\mathrm{CO}_{2} & 8 \cdot 7 & 7 \cdot 6 & 32 \cdot 7 & 51 \cdot 0 \\ & \text { Acetate } & 22 \cdot 5 & 17 \cdot 7 & 23 \cdot 1 & 36 \cdot 7 \\ & \text { Pyruvate } & 21 \cdot 1 & 17 \cdot 2 & 21 \cdot 8 & 39 \cdot 9 \\ & \text { Succinate } & 27 \cdot 3 & 18 \cdot 8 & 19 \cdot 8 & 34 \cdot 1 \\ & \text { Glutamate } & 17 \cdot 8 & 19 \cdot 0 & 21 \cdot 4 & 41 \cdot 7 \\ & \text { Sucrose } & 7 \cdot 9 & 11 \cdot 3 & 31 \cdot 9 & 48 \cdot 9\end{array}$

large-scale incorporation of $\left[{ }^{14} \mathrm{C}\right]$ formate into nucleic acids [hot $5 \%(\mathrm{w} / \mathrm{v})$ trichloroacetic acid-soluble fractions] occurred when $\left[{ }^{14} \mathrm{C}\right]$ formate was assimilated by bacteria using thiosulphate, acetate, succinate or sucrose separately as growth substrate (Table 6). Similarly, heavier labelling of lipid [70\% (v/v) ethanol and ether/ethanol $(1: 1)$ fractions] by $\left[{ }^{14} \mathrm{C}\right]-$ acetate occurred in organisms growing on formate or thiosulphate than on acetate, with comparable lowering of protein and nucleic acid labelling.

Analysis of nucleic acid fractions (Table 7) demonstrated that all four bases were labelled from $\left[{ }^{14} \mathrm{C}\right]$ formate and that when formate was the sole carbon source the labelling would be a measure of the concentration of each base in the nucleic acid. Similarly, with bacteria grown on $\left[{ }^{14} \mathrm{C}\right]$ acetate or ${ }^{14} \mathrm{CO}_{2}$ plus thiosulphate as sole growth substrates, equivalent labelling of all bases would be expected and was approximated experimentally (Table 7), giving guanine plus cytosine contents $(\mathrm{mol} \%$ ) of the total nucleic acid fractions of $61 \cdot 8$, 59.5 and 62.7 for organisms growing, respectively, on formate, acetate and thiosulphate plus $\mathrm{CO}_{2}$. Nucleic acid labelling was similar from ${ }^{14} \mathrm{CO}_{2}$ by bacteria growing on formate or thiosulphate. $\left[{ }^{14} \mathrm{C}\right]$ Formate was incorporated principally into the purines by bacteria growing on $\mathrm{CO}_{2}$ (with thiosulphate oxidation), acetate, succinate or sucrose. Conversely, $\left[{ }^{14} \mathrm{C}\right]$ acetate was incorporated largely into pyrimidines when added to cultures growing on formate, autotrophically on thiosulphate or on sucrose. Acetate labelling of the bases was similar for bacteria growing on acetate, pyruvate, succinate or glutamate (Table 7).

Chromatography of hydrolysed proteins [hot $5 \%(\mathrm{w} / \mathrm{v})$ trichloroacetic acid-insoluble residues] from the ${ }^{14} \mathrm{C}$-labelled bacteria showed incorporation of $\left[{ }^{14} \mathrm{C}\right]$ formate into most amino acids regardless of the major growth substrate, but preferential incorporation into serine plus glycine and histidine by organisms growing on thiosulphate, acetate, succinate and sucrose (Table 8). Autotrophic organisms (growing on thiosulphate plus $\mathrm{CO}_{2}$ or formate) incorporated acetate- ${ }^{14} \mathrm{C}$ into all amino acids, but showed marked preferential incorporation into glutamate, proline, arginine and leucine (Table 8), resembling what would be found with obligately lithotrophic thiobacilli (Kelly, 1967, 1971). 


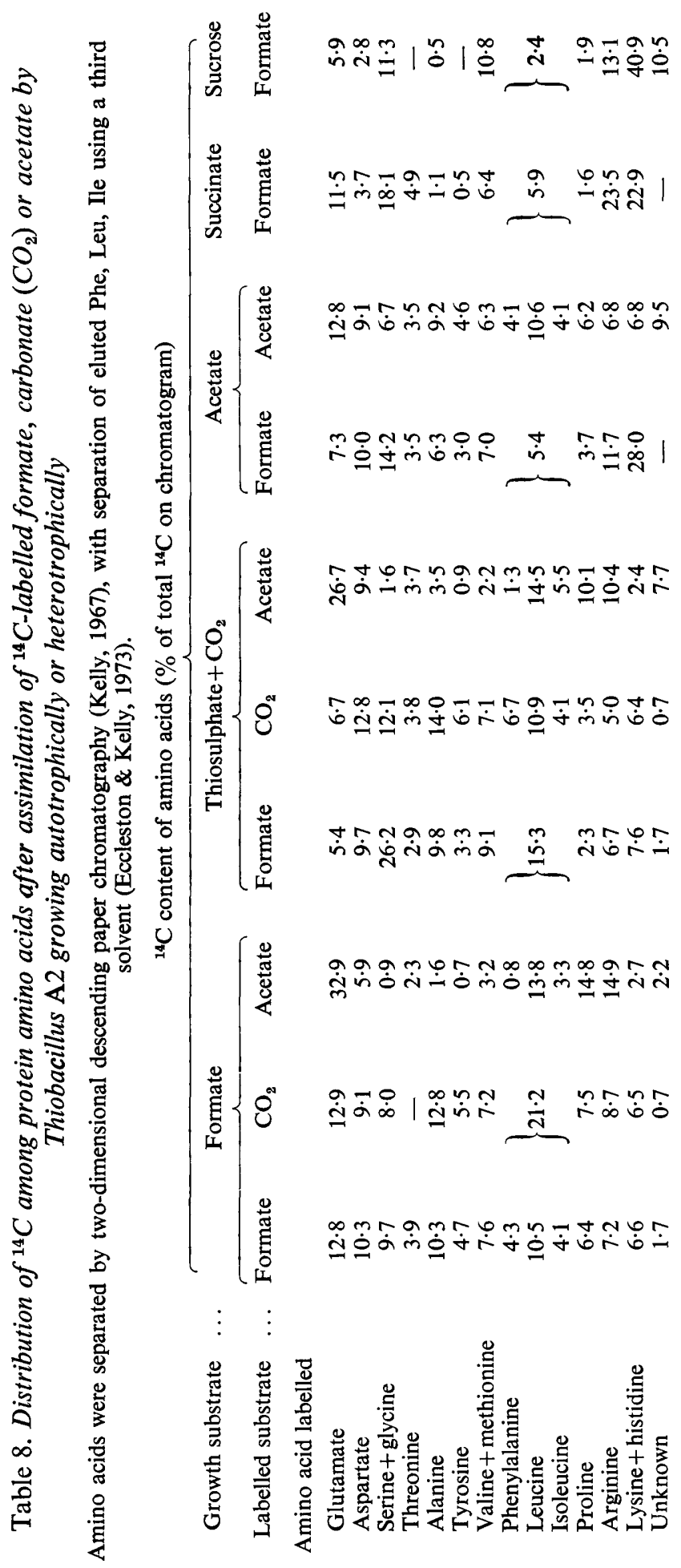


Table 9. Constants obtained by least squares fits of selected kinetic models to growth data of Thiobacillus A2 growing in extended culture on formate

\begin{tabular}{|c|c|c|c|c|c|}
\hline $\begin{array}{l}\text { Function } \\
\text { fitted* }\end{array}$ & $\begin{array}{l}\mu_{\max } \\
\left(\mathrm{h}^{-1}\right)\end{array}$ & $\begin{array}{c}K_{\mathrm{s}} \\
(\mathrm{mM})\end{array}$ & $\begin{array}{r}K_{\mathrm{i}} \\
(\mathrm{mM})\end{array}$ & $\underset{(\mathrm{mM})}{K}$ & $\begin{array}{l}\text { Minimal sum of } \\
\text { squared residuals }\end{array}$ \\
\hline 1 & 0.662 & 56.97 & $57 \cdot 06$ & & 0.00703 \\
\hline 2 & $9 \cdot 288$ & $1237 \cdot 00$ & 0.98 & $267 \cdot 25$ & 0.00872 \\
\hline 3 & 0.405 & 33.92 & $137 \cdot 85$ & & 0.00256 \\
\hline 4 & 1.019 & $114 \cdot 50$ & $101 \cdot 72$ & & 0.00275 \\
\hline $3 a$ & 0.299 & $26 \cdot 50$ & 187.00 & & 0.00289 \\
\hline
\end{tabular}

* Equations for these functions are given by Dijkhuizen \& Harder (1975) and models 3 and 3a are described in the text.

\section{DISCUSSION}

The incorporation patterns of $\left[{ }^{14} \mathrm{C}\right]$ formate and ${ }^{14} \mathrm{CO}_{2}$, the presence of high specific activity of ribulosebisphosphate carboxylase and the equivalence of formate-carbon and $\mathrm{CO}_{2}$ for growth on formate as sole energy substrate all demonstrate that Thiobacillus A2 employs the Benson-Calvin reductive pentose phosphate cycle for growth on formate. In this respect it is similar to Pseudomonas oxalaticus (Quayle \& Keech, 1959), but it is, in addition, capable of chemolithotrophic and autotrophic growth using thiosulphate and $\mathrm{CO}_{2}$. The specific activity of ribulosebisphosphate carboxylase in thiosulphate-grown autotrophic Thiobacillus A2 [50 to $70 \mathrm{nmol} \mathrm{CO}_{2} \mathrm{~min}^{-1}$ (mg protein) ${ }^{-1}$ ] (compare to the value of 48.8 shown by Charles \& White, 1976) is of the same order as that in formate-grown organisms [60 to $115 \mathrm{nmol} \mathrm{CO} \mathrm{Cm}^{-1}$ (mg protein) ${ }^{-1}$ ], and similar to that found in Thiobacillus novellus grown on formate or thiosulphate [ 83 or $32 \mathrm{nmol}$ phosphoglycerate formed $\min ^{-1}$ (mg protein) ${ }^{-1}$, respectively; Chandra \& Shethna, 1977]. The carboxylase activity necessary to sustain a growth rate of $0.1 \mathrm{~h}^{-1}$ [i.e. producing $0 \cdot 1 \mathrm{~g}$ organisms containing about $64 \%$ (w/w) protein (g organisms) ${ }^{-1} \mathrm{~h}^{-1}$ ] corresponds to about $96 \mathrm{nmol} \mathrm{CO}_{2} \mathrm{~min}^{-1}$ (mg protein $)^{-1}$, indicating that the observed values are adequate to explain growth on formate using the Calvin cycle.

Formate incorporated by Thiobacillus A2 growing heterotrophically or autotrophically with thiosulphate is assimilated largely as formate and exhibits the more restricted metabolism observed during formate assimilation by a heterotroph such as Escherichia coli (Roberts et al., 1955) and by obligate lithotrophs such as Thiobacillus neapolitanus (Kelly, 1970) and Chlorobium thiosulfatophilum (Kelly, 1974). Thus major derivatives from formatecarbon were adenine, guanine and amino acids metabolically close to formate such as glycine, serine and histidine. Even on thiosulphate, where the Calvin cycle also functions, formate assimilation would appear to proceed at least in large measure by direct incorporation rather than via $\mathrm{CO}_{2}$. Under heterotrophic conditions, when the carboxylase is repressed, direct incorporation is probably the major route for assimilation. During autotrophic growth on either formate or thiosulphate, the much heavier labelling by $\left[{ }^{14} \mathrm{C}\right]$ acetate of glutamate, proline, arginine and leucine relative to aspartate than with acetate-grown organisms (Table 8) indicated a biosynthetic role for the tricarboxylic acid cycle predominantly for the conversion of acetate to glutamate via 2-oxoglutarate, as occurs exclusively in obligate chemolithotrophs (Smith et al., 1967; Kelly, 1971). The reported absence of 2-oxoglutarate dehydrogenase from autotrophic Thiobacillus A2 (Peeters et al., 1970) suggests that the observed labelling of aspartate-family amino acids was due to a functional glyoxylate bypass, the enzymes for which are present in autotrophic Thiobacillus A2 (Peeters et al., 1970). These experiments and others (Whittenbury \& Kelly, 1977) demonstrate the strong regulatory control exhibited by Thiobacillus A2 over the selection of pathways for intermediary metabolism dependent on the growth substrate conditions.

Taking the value of true growth yield $\left(Y_{\mathrm{a}}\right)$ of $4 \cdot 2 \mathrm{~g}$ dry wt (mol formate) ${ }^{-1}$ calculated from Fig. 1 on the assumption of a linear relationship between $Y^{-1}$ and $\mu^{-1}$, one can 
estimate the energy conservation during formate oxidation as has previously been done for chemolithotrophic thiobacilli (Eccleston \& Kelly, 1978; Justin \& Kelly, 1978). Thiobacillus A2 contains $44 \%$ (w/w) carbon on a dry weight basis (A. L. Smith \& D. P. Kelly, unpublished data), so the apparent maximum yield of 4.2 represents the fixation of $0.154 \mathrm{~mol} \mathrm{\textrm {CO } _ { 2 }}$ for $1 \mathrm{~mol}$ formate oxidized. By the Calvin cycle, this requires $0.462 \mathrm{~mol} \mathrm{ATP}$ and $0.308 \mathrm{~mol}$ NADH. Formate oxidation could reduce $1 \mathrm{~mol} \mathrm{NAD}^{+}$per mol formate; so, for each $1 \mathrm{~mol}$ formate oxidized, $0.308 \mathrm{~mol}$ donates reducing equivalents for $\mathrm{NAD}^{+}$reduction for the observed $\mathrm{CO}_{2}$-fixation, leaving $0.692 \mathrm{~mol}$ to be oxidized through ATP-generating energetic metabolism. The total ATP requirement is of the order $0.462 \mathrm{~mol}$ for $\mathrm{CO}_{2}$-fixation and a further $0.146 \mathrm{~mol}$ for biosynthesis from the hexose level (according to Stouthamer, 1973), making $0.608 \mathrm{~mol}$ ATP to be synthesized during the oxidation for $0.692 \mathrm{~mol}$ formate. If this calculation is a reasonable approximation, a $\mathrm{P} / \mathrm{O}$ ratio of 0.88 is indicated for energyyielding formate oxidation. The transport of formic acid into the cell is, however, energyrequiring and in Paracoccus denitrificans requires 0.5 ATP per mol formate. Consequently, the oxidation of $0.692 \mathrm{~mol}$ formate in the above calculation must be accompanied by the synthesis of at least $1 \cdot 108 \mathrm{ATP}$, giving a $\mathrm{P} / \mathrm{O}$ ratio of $1 \cdot 6$, which is probably indicative of two coupling sites operating in Thiobacillus A2 during formate oxidation.

At concentrations above about $40 \mathrm{mM}$, formate became inhibitory, depressing growth rate in extended cultures and thus making estimation of true $K_{8}$ and $\mu_{\max }$ difficult. A similar effect in Pseudomonas oxalaticus was discussed by Dijkhuizen \& Harder (1975), who employed a computer analysis to determine rate constants and analyse the kinetics of the substrate inhibition. An obvious difference between Thiobacillus A2 and P. oxalaticus, apparent in the growth rate data, was that the $K_{\mathrm{g}}$ for formate in the former was obviously considerably greater than the value of 0.5 to $1.0 \mathrm{~mm}$ indicated for $P$. oxalaticus (Dijkhuizen \& Harder, 1975). Our data were subjected to non-linear least squares fits for each of the four models listed by Dijkhuizen \& Harder (1975), using the University of Warwick Computer Unit Burroughs B6700 computer. This analysis showed great variation among the models and vague estimates within each particular model (Table 9). As found by Dijkhuizen \& Harder (1975), model 2 was wholly unsuitable. The most serious criticism, however, was the observation that the computed $K_{\mathrm{a}}$ values were not the formate concentration $(s)$ at which $\mu=\mu_{\max } / 2$ as required for Michaelis-Menten kinetics. $K_{s}$ would have tended to this value for models 1 and 4 if $K_{\mathrm{s}} \ll K_{\mathrm{1}}$ which was true for the $P$. oxalaticus data, but not for Thiobacillus A2. Since model 3, i.e. $\mu=\mu_{\max }\left[\exp \left(-s / K_{\mathrm{i}}\right)-\exp \left(-s / K_{\mathrm{s}}\right)\right]$, appeared to fit the data least badly, this was modified, to model $3 \mathrm{a}$, by adding the constraint that $K_{\mathrm{a}}$ must be the value of $s$ at which $\mu=\mu_{\max } / 2$, i.e. $0 \cdot 5=\exp \left(-K_{\mathrm{s}} / K_{\mathrm{f}}\right)-\exp (-1) ; K_{\mathrm{s}}=-K_{\mathrm{f}} \times \log _{\mathrm{e}}$ $[0 \cdot 5+\exp (-1)] ; K_{\mathrm{s}}=K_{\mathrm{i}} \times 0 \cdot 141702 \ldots$ This considerably reduced the standard errors on the estimated variables and improved the internal estimation of the kinetic parameters being sought (Table 9). $K_{\mathrm{s}}$ and $K_{\mathrm{f}}$ were thus indicated to be 26.5 and $187 \mathrm{mM}$-formate and true $\mu_{\max }$ (in the absence of inhibitory effects) to be $0.299 \mathrm{~h}^{-1}$. The theoretical maximum observable value for $\mu$ became $0 \cdot 186$, occurring when $s=\left[K_{8} K_{1}\left(\log _{e} K_{1}-\log _{8} K_{8}\right)\right] /$ $\left(K_{\mathrm{i}}-K_{8}\right)$, i.e. at $60.3 \mathrm{mM}$-formate. In fact the maximum value observed for $\mu$ was 0.198 (at $41 \mathrm{mM}$ ) between 23 to $87 \mathrm{~mm}$ formate (Table 2). This model thus seems consistent with the observed results and gives acceptable estimates of the kinetic constants for substrateinhibited growth on formate by Thiobacillus A2. The apparent $K_{\mathrm{s}}$ is higher than might be deduced from chemostat culture (J. C. Gottschal \& J. G. Kuenen, unpublished work) where, at a dilution rate of $0 \cdot 16 \mathrm{~h}^{-1}$, the formate concentration was below $0 \cdot 3 \mathrm{mM}$.

In future work with Thiobacillus A2, its reported ability (Taylor \& Hoare, 1969) to grow on methanol needs reinvestigation: if it proves capable of growth on methanol, it will be of considerable importance to determine if carbon assimilation from methanol as well as formate proceeds by the Calvin cycle as in Paracoccus denitrificans (Cox \& Quayle, 1975; van Verseveld \& Stouthamer, 1978), or whether it is able to develop the ribulose monophosphate or serine pathway for methanol metabolism as in the methylotrophs (Whitten- 
bury \& Kelly, 1977; Quayle, 1972). Such a combination of metabolic potential may exist in T. novellus (Chandra \& Shethna, 1977), although other organisms capable of using both methanol and formate employ either the Calvin cycle (van Verseveld \& Stouthamer, 1978) or the serine pathway as in Pseudomonas AM1 (Anthony, 1975) for the assimilation of both substrates. Growth on formate by Thiobacillus A2 is clearly dependent on the inducible formate dehydrogenase (Taylor \& Hoare, 1969). It is not capable of growth on methane or on hydrogen and carbon dioxide (D. P. Kelly, unpublished results), and, unlike $P$. oxalaticus and T. novellus (Chandra \& Shethna, 1977), it is incapable of growth on oxalate, which is, however, not inhibitory to growth on formate (D. P. Kelly, unpublished work), suggesting its autotrophy on formate to be a specialized property dependent on energy generation via formate dehydrogenation. Thiobacillus A2 thus seems to represent an organism spanning heterotrophy and thiosulphate- and formate-dependent autotrophy, but is not apparently capable of methylotrophic or hydrogen-dependent growth. It is thus less remarkably versatile than $T$. novellus (Chandra \& Shethna, 1977).

We thank the Science Research Council for partial support of this work under a research grant to D.P.K. and A.P.W. We are most grateful to Wim Harder of the University of Groningen for advice, to Keith Halstead and Mike Hunt of the University of Warwick Computer Unit for computer analysis of growth kinetic data, and to Rod Quayle, Vivien Moses and Howard Slater for advice on intermediate identification.

\section{REFERENCES}

Anthony, C. (1975). The biochemistry of methylotrophic microorganisms. Science Progress 62, 167-206.

BADGer, M. R. \& LoRIMER, G. H. (1976). Activation of ribulose-1,5-bisphosphate oxygenase. The role of $\mathrm{Mg}^{2+}, \mathrm{CO}_{2}$ and $\mathrm{pH}$. Archives of Biochemistry and Biophysics 175, 723-729.

Chandra, T. S. \& Shethna, Y. I. (1977). Oxalate, formate, formamide, and methanol metabolism in Thiobacillus novellus. Journal of Bacteriology 131, 389-398.

Charles, A. M. \& White, B. (1976). Ribulose bisphosphate carboxylase from Thiobacillus A2. Its purification and properties. Archives of Micro. biology 108, 195-202.

Cox, R. B. \& QuaYle, J. R. (1975). The autotrophic growth of Micrococcus denitrificans on methanol. Biochemical Journal 150, 569-571.

DiJkruizen, L. \& HARDER, W. (1975). Substrate inhibition in Pseudomonas oxalaticus OX1: a kinetic study of growth inhibition by oxalate and formate using extended cultures. Antonie van Leeuwenhoek 41, 135-146.

EcCleston, M. \& Kelly, D. P. (1973). Assimilation and toxicity of some exogenous $\mathrm{C}_{1}$ compounds, alcohols, sugars and acetate in the methaneoxidizing bacterium Methylococcus capsulatus. Journal of General Microbiology 75, 211-221.

Eccleston, M. \& Kelly, D. P. (1978). Oxidation kinetics and chemostat growth kinetics of Thiobacillus ferrooxidans on tetrathionate and thiosulphate. Journal of Bacteriology 134, 718-727.

Jústin, P. \& KELlY, D. P. (1978). Growth kinetics of Thiobacillus denitrificans in anaerobic and aerobic chemostat culture. Journal of General Microbiology 107, 123-130.

KELLY, D P. (1967). The incorporation of acetate by the chemoautotroph Thiobacillus neapolitanus strain C. Archiv für Mikrobiologie 58, 99-116.

Kelly, D. P. (1969). Regulation of chemoautotrophic metabolism. I. Toxicity of phenylalanine to thiobacilli. Archiv für Mikrobiologie 69, 330342.

KeLLY, D. P. (1970). Metabolism of organic acids by Thiobacillus neapolitanus. Archiv für Mikrobiologie 73, 177-192.

KELLY, D. P. (1971). Autotrophy: concepts of lithotrophic bacteria and their organic metabolism. Annual Review of Microbiology 25, 177-210.

KELLY, D. P. (1973). Metabolic control in lithotrophic bacteria. Journal of General Microbiology 75, vi-vii.

Kelly, D. P. (1974). 'Growth and metabolism of the obligate photolithotroph Chlorobium thiosulfatophilum in the presence of added organic nutrients. Archives of Microbiology 100, 163-178.

KüNen, J. G. \& VeldKAMP, H. (1972). Thiomicrospira pelophila, gen. n., sp. n., a new obligately chemolithotrophic colourless sulphur bacterium. Antonie van Leeuwenhoek 38, 241-256.

LANG, E. \& LANG, H. (1972). Spezifische Farbreaktion zum direkten Nachweis der Ameisensäure. Zeitschrift für analytische Chemie 260, 8-10.

London, J. \& RitTENBERG, S. C. (1966). Effect of organic matter on the growth of Thiobacillus intermedius. Journal of Bacteriology 91, 10621069.

Peeters, T. L., LiƯ, M. S. \& Aleem, M. I. H. (1970). The tricarboxylic acid cycle in Thiobacillus denitrificans and Thiobacillus A2. Journal of General Microbiology 64, 29-35.

PIRT, S. J. (1965). The maintenance energy of bacteria in growing cultures. Proceedings of the Royal Society B163, 224-231. 
Quayle, J. R. (1972). The metabolism of onecarbon compounds by microorganisms. Advances in Microbial Physiology 7, 119-203.

QưAYle, J. R. \& KEeCH, D. B. (1959). Carbon assimilation by Pseudomoncis oxalaticus (OX1). Biochemical Journal 72, 623-637.

Roberts, R. B., Abelson, P. H., Cowie, D. B., Bolton, E. J. \& BRITTEN, R. J. (1955). Studies on biosynthesis in Escherichia coli. Publications of the Carnegie Institution of Washington 607.

Smith, A. J,, London, J. \& StanieR, R. Y. (1967). Biochemical basis of obligate autotrophy in blue-green algae and thiobacilli. Journal of Bacteriology 94, 972-983.

Stouthamer, A. H. (1973). A theoretical study of the amount of ATP required for synthesis of microbial cell material. Antonie van Leeuwenhoek $39,545-565$.
TAYlor, B. F. \& HoARe, D. S. (1969). New facultative Thiobacillus and a reevaluation of the heterotrophic potential of Thiobacillus novellus. Journal of Bacteriology 100, 487-497.

Tuovinen, O. H. \& Kelly, D. P. (1973). Studies on the growth of Thiobacillus ferrooxidans. Archiv für Mikrobiologie 88, 285-298.

Verseveld, H. W. VAN \& Stouthamer, A. H. (1978). Growth yields and the efficiency of oxidative phosphorylation during autotrophic growth of Paracoccus denitrificans on methanol and formate. Archives of Microbiology 118, 21-26.

Whittenbury, R. \& Kelly, D. P. (1977). Autotrophy: a conceptual phoenix. Symposia of the Society for General Microbiology 27, 121-149.

WooD, A. P. \& Kelly, D. P. (1977). Heterotrophic growth of Thiobacillus A2 on sugars and organic acids. Archives of Microbiology 113, 257-264. 